\title{
IN VITRO LEISHMANICIDAL, ANTIBACTERIAL, ANTIFUNGAL, ANTICANCER (MCF-7, 3 T3 AND HELA CELL LINES) ACTIVITIES OF EXTRACT AND FRACTIONS OF PEROTIS HORDEIFORMIS AND GC-MS ANALYSIS OF PEROTIS HORDEIFORMIS WHOLE PLANT BUTANOL FRACTION (PHWBF)
}

\author{
Abdul, M. K. ${ }^{1}$ - MuHAmmad, A. P. ${ }^{1}-$ JAhANGIR, K. A. ${ }^{1 *}$ - MuHAMmad, A. ${ }^{2}-$ Ali, A. ${ }^{3}-$ \\ SHAHABUdDIN, K. ${ }^{4}$ - GHULAM, M. K. ${ }^{5}$ - NAZIMA, Y. K. ${ }^{1}$ - BASIRA, A. ${ }^{6}$ - TEHMINA, A. ${ }^{7}$ - \\ MUHAMMAD, I. ${ }^{1}$ - MARINA, P. ${ }^{1}$ - NISAR, A. S. ${ }^{7}$ - NIZAM, B. ${ }^{5}-$ JAVED, K. ${ }^{8}$ \\ ${ }^{1}$ Institute of Biochemistry, University of Balochistan, Quetta 87300, Pakistan \\ (phone: +92-321-812-6298) \\ ${ }^{2}$ Faculty of Marine Sciences, Lasbella University, Lasbella 90150, Pakistan \\ ${ }^{3}$ Department of Microbiology, University of Balochistan, Quetta 87300, Pakistan \\ ${ }^{4}$ Department of Zoology, University of Balochistan, Quetta 87300, Pakistan \\ ${ }^{5}$ Department of Chemistry, University of Balochistan, Quetta 87300, Pakistan \\ ${ }^{6}$ Department of Botany, University of Balochistan, Quetta 87300, Pakistan \\ ${ }^{7}$ Faculty of Pharmacy, University of Balochistan, Quetta 87300, Pakistan \\ ${ }^{8}$ Department of Microbiology, Quaid-i-Azam University, Islamabad 45320, Pakistan \\ ${ }^{*}$ Corresponding author \\ email: jahangir.biochemist@yahoo.com
}

(Received 20 $0^{\text {th }}$ Apr 2020; accepted $10^{\text {th }}$ Jul 2020)

\begin{abstract}
In this research study, leishmanicidal, antibacterial, antifungal, anticancer (MCF-7, 3T3 and HeLa cell lines) activities and GC-MS studies of Perotis hordeiformis extract and fractions were examined. Leishmanicidal bioassay, 96 Well Plate Method, Agar tube dilution method and MTT assay were the methods used for leishmanicidal, antibacterial, antifungal and anticancer activities. Perotis hordeiformis whole plant butanol fraction (PHWBF) exhibited leishmanicidal activity with $\mathrm{IC}_{50} 53.31 \pm$ 0.59. Perotis hordeiformis whole plant hexane fraction (PHWHF) showed activity against bacteria such as Staphylococcus aureus having an inhibition percentage of 58.5\%. Perotis hordeiformis whole plant methanol extract (PHWME) showed activity against fungi such as Microsporum canis and Fusarium lini having an inhibition percentage of 55\% and 50\%, respectively. Perotis hordeiformis whole plant hexane fraction (PHWHF) showed activity against Aspergillus niger having an inhibition percentage of $40 \%$ while Perotis hordeiformis whole plant aqueous fraction (PHWAF) showed activity against Microsporum canis and Fusarium lini having an inhibition percentage of $100 \%$ and $40 \%$, respectively. Perotis hordeiformis whole plant butanol fraction (PHWBF) showed activity against cancer cell lines such as HeLa cell line and MCF-7 cell line with an inhibition percentage of 55\% and 48\%, respectively. Other extract and fractions were less active against cancer cell lines. GC-MS analysis showed 8 compounds in Perotis hordeiformis whole plant butanol fraction (PHWBF) which exhibited leishmanicidal and anticancer activities.
\end{abstract}

Keywords: leishmaniasis, bacterial strains, fungal strains, cell lines, PHWME, PHWHF, PHWAF, $P H W B F$ 


\section{Introduction}

Traditional plants are the main sources of phytochemicals, used for the preservation of human health and alleviating infectious diseases of mankind since prehistoric times. At present, the entire world has interest in green medicines and demands medicines originating from traditional plants rather than from a synthetic source. This is due to the fact that traditional drugs are safer than synthetic medicines which have toxicity and side effects. This stimulates the researchers to develop new medicines against microbes (Cordell et al., 2000; Nair et al., 2007). The drugs which are synthesized, are expensive, have side effects and the diseases are not properly treated. Hence, new antimicrobial agents are needed to be developed from traditional plant sources (Sieradzki et al., 1999; Dabur et al., 2007). According to the $\mathrm{WHO}, 80 \%$ of the population of the world use traditional medicines to cure infectious diseases (WHO, 1993). The compounds which are extracted from plant sources are more than $50 \%$ of current drugs (Baker et al., 1995). The medicinal plant, Perotis hordeiformis is a short lived perennial or annual and belongs to the Poaceae family. Sandy places are the main locations for the presence of this ethnomedicinal plant. This traditional plant is mainly distributed in Nepal, Thailand, Indonesia, India, Pakistan, Sri Lanka and Myanmer. This plant has significant antileishmanial, cytotoxic and antioxidant activities. Perotis hordeiformis has close resemblance with Perotis indica (Baloch et al., 2013). In this study, Perotis hordeiformis whole plant extract and fractions are used against leishmania major, six bacteria, five fungi and three cancer cell lines.

\section{Materials and Methods}

\section{Plant material}

Perotis hordeiformis whole plant was the plant material in this analysis.

\section{Extraction}

The medicinal plant Perotis hordeiformis was collected from Soorab, Balochistan, Pakistan and was authenticated by Prof. Dr. Rasool Bakhsh Tareen, Department of Botany, UoB, Quetta, Pakistan. Perotis hordeiformis was kept for one month under the shade and then powdered in a grinder. $1.5 \mathrm{~kg}$ powdered Perotis hordeiformis was macerated in $14 \mathrm{~L}$ of methanol for the period of seven days and then the mixture was filtered, and vaporized in a rotary evaporator. The crude extract of Perotis hordeiformis whole plant methanol extract (PHWME) was $24.52 \mathrm{~g}$.

\section{Fractionation of crude extract}

The methanolic crude extract was fractionated with n-hexane and aqueous solvents in a separatory funnel and vaporized in a rotary evaporator to form Perotis hordeiformis whole plant hexane fraction (PHWHF) $8.1 \mathrm{~g}$ and Perotis hordeiformis whole plant aqueous fraction (PHWAF) 17.3 g. Perotis hordeiformis whole plant aqueous fraction (PHWAF) was fractionated with butanol to form Perotis hordeiformis whole plant butanol fraction (PHWBF) $4 \mathrm{~g}$ (Bakht et al., 2013; Achakzai et al., 2016, 2019).

\section{Leishmanicidal bioassay}

At $3000 \mathrm{rpm}$ for $10 \mathrm{~min}$, the leishmanial parasite such as promastigotes was sedimented. This parasite was counted by Neubaur chamber, diluted to a concentration 
of $1 \times 10^{6}$ with fresh medium. In 96 well plate, $180 \mathrm{uL}$ of parasite culture was added. The sample with the concentration of $20 \mathrm{uL}$ was added and then serially diluted till final concentration of sample $1 \mathrm{ug} / \mathrm{mL}$. $1 \times 10^{6}$ cells $/ \mathrm{mL}$ of parasite density was kept for negative control while for positive control, it varied. The 96 well plate including parasites, sample, positive and negative control was kept in an incubator between 21 to $22{ }^{\circ} \mathrm{C}$ for the duration of $72 \mathrm{~h}$. With the help of Neubaur chamber, parasites with $\mathrm{IC}_{50}$ values were counted (Atta-ur Rahman et al., 2001).

\section{Antibacterial assay}

\section{6 well plate method}

For the growth of bacterial strains, Muller Hinton medium was used. McFarland turbidity index with 0.5 was used for the adjustment of inoculums. In DMSO, extracts/fractions were added and from this stock solution were formed. In wells, media and samples were added while control wells were without extracts and fractions. Up to $200 \mathrm{uL}$, the wells were filled. $5 \times 10^{6}$ cells were added in both control and test wells, which were then sealed with parafilm and kept in an incubator for 18-20 h. Alamar Blue Dye was added to all wells, which were then shaken for 2-3 $\mathrm{h}$ at $80 \mathrm{RPM}$. Blue to pink color change of dye indicated the growth of bacteria. Absorbance was recorded at 570 nm with ELISA reader (Pettit et al., 2005).

\section{Antifungal assay}

\section{Agar tube dilution method}

In this assay, in $1 \mathrm{~mL}$ of DMSO, $24 \mathrm{mg}$ of sample was dissolved. SDA with the concentration of $32.5 \mathrm{~g}$ was dissolved in $0.5 \mathrm{~L}$ of Distilled water. With the help of steam, this growth medium was completely dissolved. This medium with $4 \mathrm{~mL}$ was poured in tubes with screw cap, autoclaved for $15 \mathrm{~min}$ at $121^{\circ} \mathrm{C}$, cooled till $50{ }^{\circ} \mathrm{C}$. $66.6 \mathrm{uL}$ of sample was loaded into non-solidified SDA. At room temperature, in a slanting position, tubes were solidified. Fungus was inoculated with $4 \mathrm{~mm}$ diameter into tubes. In other media, reference antifungal drug and DMSO were used as positive and negative control. Tubes were kept in an incubator for one week at $27-29^{\circ} \mathrm{C}$, and examined twice in a week (Choudhary et al., 1995).

Calculating Inhibition \% of fungal growth

$$
\text { Inhibition } \%=100-\frac{\text { linear growth in test }(\mathrm{mm})}{\text { linear growth in control }(\mathrm{mm})} \times 100
$$

\section{MTT assay}

In this study, cancer cell lines were cultured in Dulbecco's Eagle modified medium with $10 \%$ FBS, $2 \%$ antibiotics were used and then kept in $5 \% \mathrm{CO}_{2}$ in incubator at 37 ${ }^{\circ} \mathrm{C}$. After the development of confluency, cell lines were harvested. In a 96 well flat, $5 \times 10^{4}$ cells/well were added and then after one day, sample with the concentration of $50 \mathrm{ug} / \mathrm{mL}$ was added, and kept for 48 hours in an incubator. The sample was removed after incubation. MTT with the concentration of $0.5 \mathrm{mg} / \mathrm{mL}$ was added, kept at $37{ }^{\circ} \mathrm{C}$ for hours in an incubator. Formazan crystals were formed when MTT was reduced. With the help of 100 ul DMSO, Formazan crystals were dissolved. Micro-plate reader was used for recording absorbance at $570 \mathrm{~nm}$ (Spectra Max plus, Molecular Devices, 
CA, USA). In this assay, doxorubicin was used as a standard drug. The decrease in viable cells or percent inhibition was calculated with the help of the following formula:

$$
\begin{aligned}
& \quad \% \text { Inhibition }= \\
& 100-\frac{\text { mean of O.D. of test compound }- \text { mean of O.D. of negative control }}{\text { mean of O.D. of positive control - mean of O.D. of negative control }} \times 100
\end{aligned}
$$

For the calculation of $\mathrm{IC}_{50} 20 \mathrm{mM}$ stock solution of extracts/fractions were diluted into working solution with $50 \mathrm{uM}$ and then in order to get less than 50 percent inhibition, working solution was further diluted in serial dilutions. With the help of EZfit5 software, IC50 was calculated (Scudiere et al., 1988).

\section{Gas chromatography mass spectrometry (GC-MS) analysis triple quadrupole acquisition method MS parameters}

For identification and quantification of Perotis hordeiformis compounds: 2 ul of Perotis hordeiformis extract or fraction was directly injected into the gas chromatograph mod.6890N Network GC System (Agilent Technologies Palo Alto, CA) together in the presence of mass spectrometer mod. 5973 Network Mass Selective Detector (Agilent Technologies Palo Alto, CA) and furnished in the presence of a column HP-5MS (30 m length, $0.25 \mathrm{~mm}$ interior diameter, $0.25 \mathrm{um}$ film width Agilent Technologies, Palo Alto, CA). Helium gas was off. Injection was made into a split-splitless injector (split ratio 30:1) at $250^{\circ} \mathrm{C}$. The oven program was the following: $70^{\circ} \mathrm{C}$ for $3 \mathrm{~min}$ then $6{ }^{\circ} \mathrm{C} / \mathrm{min}$ to 180 for $5 \mathrm{~min}$, then $6{ }^{\circ} \mathrm{C} / \mathrm{min}$ to $280{ }^{\circ} \mathrm{C}$ for $10 \mathrm{~min}$, then $8{ }^{\circ} \mathrm{C} / \mathrm{min}$ to $290{ }^{\circ} \mathrm{C}$ for $20 \mathrm{~min}$. The MSD transfer line was set at a temperature of $250{ }^{\circ} \mathrm{C}$; MSD temperature quadrupole was of $150{ }^{\circ} \mathrm{C}$ and ionization temperature was $230{ }^{\circ} \mathrm{C}$, Mass spectra were seventy electrovolts and scan achievement was accomplished in the series between thirty-five and $300 \mathrm{~m} / \mathrm{z}$. The identification of the components of the Perotis hordeiformis extract or fraction was assigned by matching their mass spectra with those available in the libraries NIST 02 and WILEY (El-Wakil et al., 2015).

\section{Results and Discussion}

Perotis hordeiformis whole plant butanol fraction (PHWBF) exhibited leishmanicidal activity with $\mathrm{IC}_{50} 53.31 \pm 0.59$. None of other Perotis hordeiformis extract and fractions exhibited leishmanicidal activity. Leishmanicidal activities of extract and fractions of Perotis hordeiformis are shown in Table 1.

Table 1. Leishmanicidal analysis of extract/fractions of whole plant of Perotis hordeiformis

\begin{tabular}{c|c}
\hline Extract/Fractions & IC $\mathbf{5 0}(\mathbf{u g} / \mathbf{m L}) \pm$ S.D. \\
PHWME & $>100$ \\
PHWHF & $>100$ \\
PHWAF & $>100$ \\
PHWBF & $53.31 \pm 0.59$ moderate activity \\
Standard (Pentamidine) & $4.08 \pm 0.8$ \\
Standard (Amphotericin B) & $0.30 \pm 0.4$ \\
\hline
\end{tabular}

Perotis hordeiformis whole plant hexane fraction (PHWHF) showed activity against bacteria such as Staphylococcus aureus having an inhibition percentage of $58.5 \%$. 
Perotis hordeiformis whole plant methanol extract (PHWME), Perotis hordeiformis whole plant aqueous fraction (PHWAF) and Perotis hordeiformis whole plant butanol fraction (PHWBF) showed no antibacterial activity. The antibacterial activities of Perotis hordeiformis whole plant extract and fractions are shown in Table 2.

Table 2. Antibacterial activities of Perotis hordeiformis whole plant extract and fractions

\begin{tabular}{|c|c|c|c|c|c|c|}
\hline & $\begin{array}{c}\text { Escherichia } \\
\text { coli } \\
(\%) \\
\text { Inhibition }\end{array}$ & $\begin{array}{c}\text { Bacillus } \\
\text { subtilis } \\
(\%) \\
\text { Inhibition }\end{array}$ & $\begin{array}{c}\text { Shigella } \\
\text { flexenari } \\
(\%) \\
\text { Inhibition }\end{array}$ & $\begin{array}{c}\text { Staphylococcus } \\
\text { aureus } \\
(\%) \\
\text { Inhibition }\end{array}$ & $\begin{array}{c}\text { Pseudomonas } \\
\text { aeruginosa } \\
(\%) \\
\text { Inhibition }\end{array}$ & $\begin{array}{l}\text { Salmonella } \\
\text { typhi } \\
(\%) \\
\text { Inhibition }\end{array}$ \\
\hline PHWME & - & $19 \%$ & - & $7.2 \%$ & - & - \\
\hline PHWHF & - & $11.5 \%$ & - & $58.5 \%$ & - & - \\
\hline PHWAF & - & - & - & - & - & - \\
\hline PHWBF & - & - & - & - & - & - \\
\hline $\begin{array}{c}\text { Standard } \\
\text { (ofloxacin) }\end{array}$ & $87.6 \%$ & $95.6 \%$ & - & 93.7 & $95.5 \%$ & $96.2 \%$ \\
\hline
\end{tabular}

Perotis hordeiformis whole plant methanol extract (PHWME) showed activity against fungi such as Microsporum canis and Fusarium lini having an inhibition percentage of $55 \%$ and $50 \%$. Perotis hordeiformis whole plant hexane fraction (PHWHF) showed activity against Aspergillus niger having an inhibition percentage of $40 \%$ while Perotis hordeiformis whole plant aqueous fraction (PHWAF) showed activity against Microsporum canis and Fusarium lini having an inhibition percentage of $100 \%$ and $40 \%$. Perotis hordeiformis whole plant butanol fraction (PHWBF) showed no antifungal activity. The antifungal activities of Perotis hordeiformis whole plant extract and fractions are shown in Table 3.

Table 3. Antifungal activities of Perotis hordeiformis whole plant extract and fractions

\begin{tabular}{|c|c|c|c|c|c|}
\hline & $\begin{array}{c}\text { Candida albicans } \\
(\%) \\
\text { Inhibition/MIC }\end{array}$ & \begin{tabular}{|c|} 
Trichphyton \\
rubrum \\
$(\%)$ \\
Inhibition/MIC
\end{tabular} & $\begin{array}{c}\text { Aspergillus niger } \\
(\%) \\
\text { Inhibition/MIC }\end{array}$ & $\begin{array}{c}\text { Microsporum canis } \\
(\%) \\
\text { Inhibition/MIC }\end{array}$ & $\begin{array}{c}\text { Fusarium lini } \\
(\%) \\
\text { Inhibition/MIC }\end{array}$ \\
\hline PHWME & $0 \%$ & $0 \%$ & $0 \%$ & $55 \%$ & $50 \%$ \\
\hline PHWHF & $0 \%$ & $0 \%$ & $40 \%$ & $0 \%$ & $20 \%$ \\
\hline PHWAF & $12.5 \%$ & $0 \%$ & $30 \%$ & $100 \%$ & $40 \%$ \\
\hline PHWBF & $0 \%$ & $0 \%$ & $0 \%$ & $0 \%$ & $0 \%$ \\
\hline \begin{tabular}{c|} 
Standard \\
(Miconazole) \\
Mic (ug/mol) \\
\end{tabular} & 113.5 & 97.8 & 20.70 & 98.1 & 73.50 \\
\hline
\end{tabular}

Perotis hordeiformis whole plant butanol fraction (PHWBF) showed anticancer activity against HeLa cell line and MCF-7 cell line with percent inhibition 55\% and 48\%. Other extract and fractions are less active against cancer cell lines. The anticancer activities of extract and fractions of whole plant of Perotis hordeiformis are shown in Table 4.

Molecular formula, molecular mass, structure, m/z and RT of compounds 1-8 of Perotis hordeiformis whole plant butanol fraction (PHWBF) are shown in Tables 5 and 6 while mass spectra interpretation of compounds 1-8 of Perotis hordeiformis whole plant butanol fraction (PHWBF) are shown in Tables 7 and 8 . 


$$
\text { - } 6534 \text { - }
$$

Table 4. Anticancer activities of extract and fractions of whole plant of Perotis hordeiformis

\begin{tabular}{c|c|c|c}
\hline & $\begin{array}{c}\text { MCF-7 } \\
(\%) \text { Inhibition }\end{array}$ & $\begin{array}{c}3 \mathrm{~T} 3 \\
(\boldsymbol{\%}) \text { Inhibition }\end{array}$ & $\begin{array}{c}\text { HeLa } \\
\text { (\%) Inhibition }\end{array}$ \\
\hline PHWME & $12 \%$ & $25 \%$ & $36 \%$ \\
PHWHF & $8 \%$ & $32 \%$ & $32 \%$ \\
PHWAF & $16 \%$ & $25 \%$ & $6 \%$ \\
PHWBF & $48 \%$ & $25 \%$ & $55 \%$ \\
\hline Standard & $87.6 \%$ & $71 \%$ & $70 \%$ \\
Doxorubicin & \multirow{2}{*}{ Dox } & & \\
\hline
\end{tabular}

Table 5. Molecular formula, molecular mass, structure, $\mathrm{m} / \mathrm{z}$ and $R T$ of compounds $1-4$ of Perotis hordeiformis whole plant butanol fraction (PHWBF)

\begin{tabular}{|c|c|c|c|c|c|}
\hline compd & $\begin{array}{c}\text { Molecular } \\
\text { Formula }\end{array}$ & $\begin{array}{c}\text { Molecular } \\
\text { Mass }\end{array}$ & Structure & $\mathbf{m} / \mathbf{z}$ & RT \\
\hline 1 & С9H20O & 144 & & 45.1 & 6.681 \\
\hline 2 & $\mathrm{C} 8 \mathrm{H} 8 \mathrm{O}$ & 120 & & 91 & 7.503 \\
\hline 3 & C6H8O4 & 144 & & 43.1 & 9.983 \\
\hline 4 & C6H8O4 & 144 & & 53.1 & 12.39 \\
\hline
\end{tabular}


Table 6. Molecular formula, molecular mass, structure, $\mathrm{m} / \mathrm{z}$ and $R T$ of compounds 5-8 of Perotis hordeiformis whole plant butanol fraction (PHWBF)

\begin{tabular}{|c|c|c|c|c|c|}
\hline compd & $\begin{array}{l}\text { Molecular } \\
\text { Formula }\end{array}$ & $\begin{array}{l}\text { Molecular } \\
\text { Mass }\end{array}$ & Structure & $\mathbf{m} / \mathbf{z}$ & RT \\
\hline 5 & $\mathrm{C} 11 \mathrm{H} 24 \mathrm{O}$ & 172 & & 43.1 & 17.44 \\
\hline 6 & $\mathrm{C} 13 \mathrm{H} 10 \mathrm{O}$ & 182 & & 104.9 & 20.61 \\
\hline 7 & $\mathrm{C} 16 \mathrm{H} 34 \mathrm{O} 3 \mathrm{~S}$ & 306 & & 57.1 & 35.25 \\
\hline 8 & $\mathrm{C} 10 \mathrm{H} 8 \mathrm{O} 5$ & 208 & & 135 & 68.13 \\
\hline
\end{tabular}

Table 7. Mass spectra of compounds 1-4 of Perotis hordeiformis whole plant butanol fraction $(P H W B F)$

\begin{tabular}{c|l}
\hline compd & \multicolumn{1}{c}{$\mathbf{~} \mathbf{c} / \mathbf{z}$ (\% Relative abundance) } \\
\hline \multirow{2}{*}{1} & $\begin{array}{l}144\left(\mathrm{M}^{+}\right), 126(2365.9), 69(2401), 57.1(3606.8), 56.1(2876.3), 55.1(1849.7), 54(2775.9), \\
53.1(3732.9), 45.1(8743.3), 44.1(4950.7), 41.1(2064.4)\end{array}$ \\
\hline 2 & $\begin{array}{l}\left.119.9\left(\mathrm{M}^{+}\right], 13185\right), 91.9(21295), 91(83166), 88.9(4417.4), 64.9(18968), 62.9(7995.1), \\
62(3067.6), 51.1(6416.9), 50.1(3636.7), 39.1(2357.5)\end{array}$ \\
\hline 3 & $\begin{array}{l}\left.144\left(\mathrm{M}^{+}\right], 58661.2\right), 101(56580), 73(39808.6), 72(47429.7), 58(7389.8), 55.1(43751.8), \\
45.1(39179.1), 44.1(108117.2), 43(145948), 42.1(7752.4)\end{array}$ \\
\hline 4 & $\begin{array}{l}144\left(\mathrm{M}^{+}\right), 113.9(2272.7), 112.9(3354), 98(2209.6), 85(2140.8), 71(2930), 68(1637.4), \\
56.1(1855.7), 53.1(4503.1), 52(1566.3), 51.1(3247.2)\end{array}$ \\
\hline
\end{tabular}


Table 8. Mass spectra of compounds 5-8 of Perotis hordeiformis whole plant butanol fraction $(P H W B F)$

\begin{tabular}{c|l}
\hline compd & \multicolumn{1}{c}{$\mathbf{m} / \mathbf{z}$ (\% Relative abundance } \\
\hline 5 & $\begin{array}{l}172\left(\mathrm{M}^{+}\right), 97(1101.3), 84(1288.9), 83(2228.8), 70(2031.5), 69(4248.8), 57.1(4541.2), \\
56.1(5445.9), 55.1(5725.6), 43.1(8861.9), 41.1(2510.4)\end{array}$ \\
\hline 6 & $\begin{array}{l}\left.181.9\left(\mathrm{M}^{+}\right], 4016.4\right), 105.9(1127.1), 104.9(11055), 91(1654.5), 87(6040.8), 76.9(7954.4), \\
75.9(1546), 53.1(1837), 51.1(4023.6), 50.1(1050.9)\end{array}$ \\
\hline 7 & $\begin{array}{l}306\left(\mathrm{M}^{+}\right), 135(6436.7), 112.9(13869), 111.9(6419.7), 88.9(16427), 71(27183), 70(11703), \\
57.1(33305), 55.1(9046.4), 43.1(13743), 41.1(6340.2)\end{array}$ \\
\hline 8 & $\begin{array}{l}\left.208.9(\mathrm{M}+1], 672.6), 207.9\left(\mathrm{M}^{+}\right], 771.6\right), 196.9(816.7), 149(546.4), 135(1655.4), 104.9(543.5), \\
95.9(770.1), 76.9(541.6), 75(774.9), 44.1(829.8)\end{array}$ \\
\hline
\end{tabular}

\section{Conclusion}

In this research study, Perotis hordeiformis whole plant butanol fraction (PHWBF) exhibited leishmanicidal activity with $\mathrm{IC}_{50} 53.31 \pm 0.59$. None of other extract and fractions of Perotis hordeiformis exhibited leishmanicidal activity. Perotis hordeiformis whole plant hexane fraction (PHWHF) showed activity against bacteria such as Staphylococcus aureus having an inhibition percentage of 58.5\%. Perotis hordeiformis whole plant methanol extract (PHWME), Perotis hordeiformis whole plant aqueous fraction (PHWAF) and Perotis hordeiformis whole plant butanol fraction (PHWBF) showed no antibacterial activity. Perotis hordeiformis whole plant methanol extract (PHWME) showed activity against fungi such as Microsporum canis and Fusarium lini having an inhibition percentage of $55 \%$ and $50 \%$, respectively. Perotis hordeiformis whole plant hexane fraction (PHWHF) showed antifungal activity against Aspergillus niger having an inhibition percentage of $40 \%$ while Perotis hordeiformis whole plant aqueous fraction (PHWAF) showed antifungal activity against Microsporum canis and Fusarium lini having an inhibition percentage of $100 \%$ and $40 \%$, respectively. Perotis hordeiformis whole plant butanol fraction (PHWBF) exhibited no antifungal activity. Perotis hordeiformis whole plant butanol fraction (PHWBF) showed anticancer activity against HeLa cell line and MCF-7 cell line with an inhibition percentage 55\% and 48\%, respectively. Other extract and fractions are less active against cancer cell lines. GC-MS analysis showed 8 compounds in Perotis hordeiformis whole plant butanol fraction (PHWBF) which exhibited leishmanicidal and anticancer activities. In the near future, in the Institute of Biochemistry, University of Balochistan, Quetta, Pakistan, the compounds present in the Perotis hordeiformis whole plant butanol fraction (PHWBF) will be isolated and tested against cancer cell lines and leishmaniasis and will lead to drug development with least toxicity and side effects.

Acknowledgements. Authors are thankful to Hussain Ebrahim Jamal (HEJ), Research Institute of Chemistry, University of Karachi, Karachi, Pakistan, for providing biological activities, GC-MS analysis and Institute of Biochemistry, University of Balochistan, Quetta, Pakistan for providing lab facilities for extraction and fractionation. 


\section{REFERENCES}

[1] Achakzai, J. K., Anwar, M. (2016): GC-MS Analysis and Antileishmanial activity of dichloromethane fraction of Allium cepa (DFAC) in Vitro. - International Journal of Pharma and Bio Sciences 2: 40-51.

[2] Achakzai, J. K., Panezai, M. A., Kakar, M. A., Kakar, S., Khan, J., Khan, N. Y., Khilji, I., Tareen, A. K. (2019): In Vitro Anticancer MCF-7, Anti-Inflammatory, and Brine Shrimp Lethality Assay (BSLA) and GC-MS Analysis of Whole Plant Butanol Fraction of Rheum ribes (WBFRR). - BioMed Research International, Article ID: 3264846.

[3] Atta-ur-Rahman., Choudhary, M. I., Thomsen, W. J. (2001): Bioassay Techniques for Drug Development. - Harwood Academic Publishers, The Netherland, 240p.

[4] Baker, J. T., Borrıs, R. P., Carte, B., Cordell, G. A., Soejarto, D. D., Cragg, G. M., Gupta, M. P., Iwu, M. M., Madulid, D. R., Tyler, V. E. (1995): Natural Product Drug Discovery and Development New- Perspectives on İnternational Colloboration. - J. Nat. Prod. 58(9): 1325-1357.

[5] Bakht, J., Shehla, K., Mohammad, S. (2013): Antimicrobial potentials of fresh Allium cepa against gram negative bacteria and fungi. - Pakistan journal of Botany 45: 1-6.

[6] Baloch, N., Nabi, S., Yasser, M. S., Al-Kahraman, A. (2013): In vitro Antileishmanial, Cytotoxic, Antioxidant activities and Their Phytochemical Analysis on Methanolic Extract and it is Fractions of Perotis hordeiformis leaves. - Int. J. Pharm. Sci. Rev. Res. 22(2): 191-195.

[7] Choudhary, M. I., Dur-e-Shahwar, Parveen, Z., Jabbar, A., Ali, I., Atta-ur-Rahman. (1995): Antifungal steroidal lactones from Withania coagulance. - Phytochemistry 40(4): 1243-6.

[8] Cordell, G. A. (2000): Biodiversity and drug discovery -space- a symbiotic relationship. Phytochemistry 55(6): 463-480.

[9] Dabur, R., Gupta, A., Mandal, T. K., Singh, D. D., Bajpai, V. A., Gurav, M., Lavekar, G. (2007): Antimicrobial Activity of Some Indian Medicinal Plants. - Afr. J. Trad. CAM 4(3): 313-318.

[10] El-Wakil, E. A., El-Sayed, M. M., Abdel-Lateef, E. E. (2015): GC-MS Investigation of Essential oil and antioxidant activity of Egyptian White Onion (Allium cepa L.). International journal of pharma sciences and research IJPSR 6(3): 537-543.

[11] Nair, R., Chanda, S. V. (2007): Antibacterial activities of some medicinal plants of Western Region of India. - Turk J Biol 31: 231-236.

[12] Pettit, R. K., Weber, C. A., Kean, M. J., Hoffmann, H., Pettit, G. R., Tan, R., Franks, K. S., Horton, M. L. (2005): Microplate alamar blue assay for Staphylococcus epidermidis Biofilm susceptibility testing. - Antimicrob Agents Chemother 49(7): 2612-2617.

[13] Scudiere, A., Shoemaker, R. H., Paul, K. D., Monks, A., Tierney, S., Nofziger, T. H., Currens, M. J., Seniff, D., Boyd, M. R. (1988): Evaluation of a soluble tetrazolium/formazan assay for cell growth and drug sensitivity in culture using human and other tumor cell Lines. - Cancer Research 48: 4827-4833.

[14] Sieradzki, K., Wu, S. W., Tomasz, A. (1999): Inactivation of the methicillin Resistance gene mecA in vancomycin resistant Staphylococcus aureus. - Microb Drug Resist 5: 253257.

[15] World Health Organisation (1993): Summary of WHO guidelines for the assessment of herbal Medicine. - Herbal Gram 28: 13-14. 